\title{
Kirjoittamisen diskurssit lukiolaisten kirjoittamista pohtivissa teksteissä
}

\section{Johdanto}

\subsection{Tutkimuskysymykset ja tutkimuksen teoreettinen tausta}

Lukion äidinkielen ja kirjallisuuden opetuksen oppisisällöt ovat laajat. Nykyisen opetussuunnitelman mukaan kyseessä on "taito-, tieto-, kulttuuri- ja taideaine", joka "saa sisältöjä kieli-, kirjallisuus- ja viestintätieteistä sekä kulttuurin tutkimuksesta" (LOPS 2015, 40). Kirjoittaminen on monella tapaa oppiaineen ytimessä: se on paitsi opiskelun kohde myös keskeisin tapa osoittaa muiden sisältöjen osaamista. Lisäksi sitä tarvitaan monen muun oppiaineen opiskelussa. Lukion kirjoittamisen opetus on murroksessa: ylioppilaskoe on vastikään uudistunut ja muun muassa digitalisaatio sekä oppiainerajat ylittävä monilukutaidon käsite herättävät keskustelua (esim. Oja 2018).

Tässä artikkelissa tarkastelen lukiolaisten kirjoittamista ja selvitän, mitä kirjoittamisen diskursseja lukiolaisten omaa kirjoittamista pohdiskelevat tekstit kaiuttavat. Käsittelyni perustuu englantilaisen kirjoittamisen tutkijan Roz Ivaničin (2004) viitekehykseen: kirjoittamisessa ja sen oppimisessa voi olla kyse taidosta, luovuudesta tai prosessista; se voi olla tekstilajien tuottamista, sosiaalisten käytänteiden noudattamista tai sosiopoliittista toimintaa. Tutkin näitä diskursseja 50 kirjoitelmasta koostuvassa aineistossa diskurssianalyysin keinoin ja vertaan tuloksia lukion opetussuunnitelman perusteiden ja ylioppilaskokeen määräysten analyysista (Erra-Svinhufvud 2017) saatuihin tuloksiin.

Ivaničin (2004) esittelemä kirjoittamisen diskurssien malli perustuu kronologiaan ja antaa näkökulman myös suomalaisen kirjoittamisen opetuksen historiaan. Perinteisesti opetuksessa on keskitytty taitoihin, kuten oikeinkirjoitukseen ja kielioppiin. Vähitellen kirjoittamista alettiin tarkastella lisäksi luovana itseilmaisuna, jossa kirjoittajan persoonallisuuden näkyminen on tärkeää. (Ivanič 2004; ks. myös Helttunen-Julin [toim.] 2008.) 1980-luvulla yleistyi prosessikirjoittaminen (Ranta 2007), ja 2000-luvulla kirjoittamista on tarkasteltu tekstitaitojen (Grünn 2007) sekä monilukutaidon (Oja 2018) näkökulmasta. Uusimmassa opetussuunnitelmassa kirjoittaminen on aikaisempaa enemmän 
myös sosiaalista ja sosiopoliittista toimintaa (Svinhufvud-Erra 2018). Opetussuunnitelmille on tyypillistä, että uudistukset rakentuvat vanhan päälle (Kauppinen M., 2010, 299), ja suomalaisissa opetussuunnitelmissa eri kirjoittamisen diskurssit ovatkin läsnä (ErraSvinhufvud 2017). Tässä tutkimuksessa huomio kohdistuu opetussuunnitelmatekstien kirjoittamiskäsitysten sijaan yksittäisten opiskelijoiden käsityksiin.

Laadullisen tutkimukseni konteksti on monitieteinen ja melko epäyhtenäinen kirjoittamisen tutkimuksen kenttä: sekä lukion että peruskoulun kirjoittamista koskeva tutkimus on niukkaa ja hajanaista (Juvonen-Kauppinen, A.-Makkonen-Craig-Lehti-Eklund 2011; Kauppinen, M.-Pentikäinen-Hankala-Kulju-Harjunen-Routarinne 2015). Perinteisesti on tutkittu enemmän tekstituotoksia kuin kirjoittamisen prosessia, kirjoittamistapahtumaa tai kirjoittamisen sosiokulttuurista kontekstia (suomalaisesta lukiokirjoittamisen tutkimuksesta Juvonen ym. 2011; ks. myös Ivanič 2004, 222-223). Viime vuosina aiheet ovat kuitenkin monipuolistuneet ja huomiota on kiinnitetty muun muassa tekijän ääneen (Juvonen 2014), tekstilajiosaamiseen (Valtonen 2012), argumentointiin (Mikkonen 2010), kirjoittamisprosesseihin (Ranta 2007), palautekulttuuriin (Kronholm-Cederberg 2009), uusiin kirjoitustaitoihin (Kallionpää 2017) sekä kirjoittamisen esteisiin ja mahdollisuuksiin (Erra 2018). Tässä tutkimuksessa huomioni kohdistuu yhtäältä kirjoittajiin ja toisaalta kirjoittamisen kontekstiin. Kirjoittamisen diskurssit tarjoavat lukiolaisille subjektipositioita (ks. esim. Suoninen 1992; vrt. Ivanič 1998, 10), joihin opiskelijat jollakin tavalla itseään suhteuttavat. Kirjoittajat ottavat omakseen vain joitakin käytänteitä ja diskursseja, ja valinnat muovaavat kirjoittajaidentiteettejä. Tutkin yksilöitä siinä mielessä, että lukiolaiset käsittelevät teksteissä itseään ja kokemuksiaan, ja sosiokulttuurista kontekstia siinä mielessä, että käytetyt diskurssit kaiuttavat ympäristön näkemyksiä (esim. Gee 2008).

Tutkimusstrategiani on diskurssintutkimus: en tulkitse opiskelijoiden kielellisten valintojen kertovan pelkästään heidän omista näkemyksistään vaan myös yhteiskunnan ja lukioinstituution ylläpitämistä käsityksistä, sillä opiskelijat hyödyntävät teksteissään erilaisia diskursiivisia resursseja (Mäntynen-Pietikäinen 2009, 18, 53). Nojaan diskurssintutkimuksen piirissä vakiintuneeseen käsitykseen, että erilaiset kontekstit ja diskurssit rakentavat identiteettejä. Vaikka identiteetin ymmärtäisikin olevan subjektiivinen kokemus itsestä, muotoutuu se sosiaalisessa ympäristössä, johon diskurssit erottamattomasti kuuluvat. (Mt. 63-64; Ivanič 1998, 17.) Lukion opetussuunnitelman perusteiden oppimiskäsityksen mukaan (LOPS 2015, 14) "opiskelija tulkitsee, analysoi ja arvioi eri muodoissa esitettyä informaatiota, rakentaa uutta tietoa ja syventää siten osaamistaan aikaisempien kokemustensa ja tietojensa pohjalta" (ks. myös LOPS 2003, 14). Lukiolaisten kirjoittamiskäsityksiä ja kirjoittamisen diskursseja voikin pitää maaperänä, jolle uutta tietoa rakennetaan. On tärkeää tutkia, millaisia kokemuksia ja millaista tietoa lukiolaisilla on kirjoittamisesta, sillä tälle pohjalle kirjoittamisen oppiminenkin perustuu.

Erilaisille diskurssintutkimuksen piirissä tehdyille tutkimuksille on yhteistä teoreettinen tausta ja ajatus kielestä sosiaalisen todellisuuden rakentajana, mutta käytössä on useita menetelmiä (Mäntynen-Pietikäinen 2009, 163). Hyödynnän tutkimuksessani 
diskurssianalyysia, joka usein jäsentyy vasta tutkimusprosessin aikana (Juhila 1999, 212213). Diskurssianalyysi jakautuu eri suuntauksiin, ja lähtökohtanani on Geen (2014, 2-15) käsitys, jonka mukaan sanominen, tekeminen sekä oleminen kohtaavat merkityksissä ja merkitykset puolestaan rakentuvat käyttöyhteyksissään sekä niitä laajemmassa sosiokulttuurisessa kontekstissa. Analyysissä keskityn kielenkäytön mikrotasoon, erityisesti sanavalintoihin, metaforiin ja painotuksiin (Mäntynen \& Pietikäinen 2009, 166-168). Analysoin lukiolaisten kirjoitelmista koostuvaa aineistoani teoriasidonnaisesti, mikä ei ole tyypillistä diskurssianalyysille. Tukeudun Ivaničin (2004) malliin, joka perustuu aiemman kirjoittamisen tutkimuksen meta-analyysiin. Vastaavanlaista, lukiokirjoittamisen tutkimukseen pohjautuvaa luokittelua on tehty myös Suomessa (Juvonen ym. 2011), ja muitakin tapoja jäsentää kirjoittamista on esitetty (esim. Hyland 2002; Lillis 2013). Muut mallit eivät tarjoudu yhtä selvästi analyysin viitekehyksiksi, ja Ivaničin mallin etu onkin, että sitä on hyödynnetty erilaisten aineistojen tarkastelussa (esim. Erra-Svinhufvud 2017; Harjunen-Rautopuro 2015; MacCarthey-Woodard-Kang 2014; Peterson-Parr-Lindgren-Kaufman 2018; Randahl 2011).

\subsection{Aineisto ja analyysiprosessin kuvaus}

Aineistoni koostuu 50:stä kirjoittamista pohdiskelevasta kirjoitelmasta, jotka olen kerännyt kolmesta kooltaan ja sijainniltaan erilaisesta lukiosta vuosina 2006, 2014 ja 2015. Kaikki tekstit on kirjoitettu äidinkielen ja kirjallisuuden oppitunnilla, joilla opiskeltiin suomea äidinkielenä. Vanhin ja uusin aineisto on kerätty tehtävänannolla "Kirjoita teksti, jossa pohdit itseäsi kirjoittajana". Vuoden 2014 aineistossa kirjoittamista sai pohtia vapaammin, koska en halunnut tehtävänannolla rajoittaa kirjoittamista. Koska opiskelijat keräystilanteessa tuskastuivat vapaaseen kirjoittamiseen, tarjosin lopulta kaksi virittelykysymystä: "Mitä on kirjoittaminen? Millainen olet kirjoittajana?"

Erilaiset keräystavat johtuvat siitä, että vanhimmat tekstit oli kirjoitettu alun perin hieman toisenlaista tutkimusta varten ja vuoden 2014 kirjoitelmia teettäessäni olin rajannut vanhimmat tekstit pois tutkimuksesta. Aineistoon tutustuessani havaitsin, että erilaisista tehtävänannoista ja eri kirjoitusajankohdista huolimatta molempien aineistojen kirjoittajat pohtivat hyvin samanlaisia asioita, minkä vuoksi oli perusteltua hyödyntää myös vanhempia tekstejä. Analysoituani aineistoa päätin täydentää sitä vielä yhden oppilasryhmän kirjoitelmilla, ja vuoden 2015 tekstejä kerätessäni hyödynsin samaa tehtävänantoa kuin vuonna 2006. Aineiston puutteena voi pitää osin erilaisia keräystapoja: tehtävänannoissa oli pieniä eroja, ja vain vuoden 2006 ja 2014 osallistujat tapasivat tutkijan. Tekstien kirjoittajat olivat hieman eri vaiheissa lukio-opintojaan, sillä aineisto kerättiin eri kursseilla ja nykymuotoisessa lukiossa kurssien suoritusjärjestyksestä voi yleensä myös poiketa.

Äidinkielen ja kirjallisuuden oppitunnin kontekstin voi arvioida vaikuttavan kirjoittamisen käsittämiseen ja käsittelemiseen. Samalla tavalla kuin aineen tekstilaji saattaa tarjota kirjoittajalle opiskelijan subjektiposition (Burgess 2012, 231), voivat tila ja tilanne vaikuttaa siihen, mitä tutkimukseen osallistuva kokee voivansa kirjoittaa. Myös kirjoittamisen opiskelun institutionaalinen konteksti on merkittävä. Tutkimukseen osallistuneet 
kirjoittajat ovat opiskelleet suomea äidinkielenä äidinkielen ja kirjallisuuden oppiaineen piirissä, ja aineistoa kerätessä olivat voimassa Lukion opetussuunnitelman perusteet 2003 (LOPS 2003). Aineiston kirjoittajat tähtäsivät todennäköisesti äidinkielen ylioppilaskokeeseen, joka heidän vuosikurssiensa opiskelijoille koostui esseekokeesta ja tekstitaidon kokeesta. Lukiosta voi kuitenkin valmistua myös ilman ylioppilastutkintoa, ja äidinkielen kokeen vaihtoehtona on suomi toisena kielenä -oppimäärän mukainen koe.

Vaikka valtakunnalliset lukion opetussuunnitelman perusteet ja ylioppilaskoe ovat olleet kaikille aineiston kirjoittajille samanlaiset, on syytä olettaa, että kirjoittamisen kouluopetus on ollut hieman erilaista vuoden 2006 opiskelijoille. Peruskoulun opetussuunnitelma ei vielä heidän opintojensa aikana korostanut tekstitaitojen merkitystä, ja kirjoitelma-aineistoa kerätessä genreosaamista painottava ylioppilaskoe oli vasta tulossa. Koska tarkoitukseni ei ole tehdä pitkittäistutkimusta, harkitsin tarkasti vanhimpien tekstien ottamista mukaan tutkimukseen. Erot eri vuosina kirjoitettujen aineistojen välillä ovat kuitenkin melko pieniä, mikä puolsi koko aineiston hyödyntämistä. Kaikissa teksteissä käsitellään jollakin tapaa kirjoittamista ja itseä kirjoittajana. Genrediskurssi ei painotu enempää vuoden 2015 kuin vuoden 2006 kirjoitelmissa, vaikka näin voisi peruskoulun erilaisen opetussuunnitelman vuoksi ehkä olettaa. Sen sijaan vuoden 2014 teksteissä tukeudutaan hieman kahta muuta osa-aineistoa enemmän genrediskurssiin sekä melko abstraktiin aiheen tarkasteluun, mitä käsittelen tuonnempana analyysin yhteydessä.

Tässä tutkimuksessa aineiston ja tutkijan välillä on vuorovaikutussuhde, sillä tekstit ovat syntyneet antamani tehtävänannon myötä ja olen siis eräällä tavalla yksi aineiston tuottajista. Tutkijana asetan aineiston kontekstiin, jossa sitä tulkitsen. (Juhila 1999, 212.) Oma taustani äidinkielenopettajana on tutkimusprosessin kannalta merkityksellinen, sillä tunnen kirjoittamisen opetusta arjen näkökulmasta ja kiinnostukseni tutkimusaiheeseen on osin ammatillista. En kuitenkaan tutki omia opiskelijoitani, jottei opettajan auktoriteettiasema tai oppilaantuntemus vaikuta liikaa tutkimukseen.

Ennen kirjoitelmien analyysia anonymisoin tekstit. Vanhimmat tekstit kirjoitin uudelleen tekstinkäsittelyohjelmalla, ja uusimmat olivat valmiiksi tekstitiedostoissa. En tehnyt tekstien kieliasuun minkäänlaisia korjauksia. Lisäsin kirjoitelmiin keräysvuoden ja järjestysnumeron: esimerkiksi 14/37 merkitsee koko aineiston 37. tekstiä vuodelta 2014. En huomioi analyysissa sukupuolta, koska se on vain yksi kirjoittamiseen vaikuttava tekijä (ks. myös Cameron 2005; Jones-Myhill 2007). Aluksi kirjoitelmien analyysi oli melko vapaata, ja ensimmäisten analyysikierrosten aikana täydensin aineistoa. Aineistoa voi pitää riittävänä, sillä uusimmissa teksteissä ei enää noussut esiin asioita, joita myös vanhemmissa teksteissä ei olisi ollut (ks. Pietikäinen-Mäntynen, 2009, 160-161). Koska samat seikat toistuvat koko aineistossa, saattaa samanlaisia näkemyksiä olla myös muilla lukiolaisilla, vaikka tilastollisiin yleistyksiin ei olekaan aihetta (Eskola-Suoranta 1998, luku 4). 


\section{Kirjoittamisen diskurssit lukiolaisten teksteissä}

Ivaničin mukaan (2004) erilaiset tavat puhua kirjoittamisesta toteuttavat kirjoittamisen diskursseja. Ivanič kuvaa artikkelissaan kuuden esittelemänsä kirjoittamisen ja sen oppimisen diskurssin taustoja sekä ilmenemistä teksteissä ja luettelee erilaisia ilmaisuja, joista diskurssin voi tunnistaa. Nojaan tähän malliin sekä siihen perustuvaan aiempaan tutkimukseen (erit. Erra-Svinhufvud 2017) analysoidessani kirjoitelma-aineistoa. Ivaničin viitekehystä on aiemmin esitelty suomeksi useissa lähteissä (mm. Erra-Svinhufvud 2017; Svinhufvud 2016), joten kuvailen kunkin diskurssin vain lyhyesti. Seuraavaksi käsittelen kirjoittamisen diskurssien ilmenemistä lukiolaisten kirjoitelmissa.

\subsection{Taitodiskurssi lukiolaisten kirjoitelmissa}

Taitodiskurssi hahmottaa kirjoittamisen kielioppitiedon soveltamisena ja oikeinkirjoitusnormien noudattamisena. Se keskittyy tekstituotokseen ja saattaa kokonaan sivuuttaa kontekstin merkityksen, jolloin kirjoittamista näyttävät ohjaavan samat säännöt kaikissa tilanteissa. (Ivanič 2004, 227-229.) Usein se kuitenkin kimputtuu yhteen muiden diskurssien kanssa (Erra-Svinhufvud 2017, 337; Randahl 2011). Taitodiskurssi näyttäytyy virheiden pohtimisena sekä kirjoittamisen ongelmien tarkasteluna erilaisten kielioppiin liittyvien käsitteiden avulla (Ivanič 2004, 228). Diskurssi näkyy valtaosassa aineistoni kirjoitelmista: monille tutkimukseeni osallistuneista lukiolaisista kirjoittaminen on virheiden tekemistä tai niiden välttämistä. Sellainen teksteistä saatu palaute, joka noudattaa taitodiskurssia, saattaa olla helppo hyväksyä, koska kieliopin ja oikeinkirjoituksen säännöt ovat ainakin osin yksiselitteiset. Seuraavissa esimerkeissä virheet ja säännöt tekevät oppimisen näkyväksi:

(1) Äidinkielen opiskelussa ja kirjoittamisessa latistaa se, että kirjoittamassani tekstissä on aina jotain väärin. En tarkoita nyt kielioppivirheitä, koska niistä tietenkin pitää huomauttaa ja haluaisin todella päästä näistä virheistä pois! $(14 / 37)$

(2) Tykkään säännöistä ja tämän takia kielioppisäännöt, pilkutukset ja oikeinkirjoitukset ovat mielestäni kivoja. On kiva huomata kehittyvän kirjoittajana enemmän ja enemmän koulussa tehtyjen kirjoitustehtävien takia. (15/45)

Taitodiskurssiin kytkeytyykin opiskelijoiden teksteissä tavoitteellisuus. Esimerkissä 1 kirjoittaja kuvaa lannistavaa palautetta, jonka voi koulukontekstissa päätellä tulevan opettajalta. Hän kuitenkin irrottaa kielioppivirheet ikävästä palautteesta. Virheet näyttäytyvät eräänlaisena olotilana, josta kirjoittaja haluaa vapautua (KS s.v. päästä). Koska taidon opettaminen on eksplisiittistä (Ivanič 2004, 227-229), on joidenkin opiskelijoiden melko helppo hahmottaa, miten oma kirjoittaminen on kehittynyt ja miten sitä voisi jatkossa kehittää, kun kirjoittamista tarkastellaan taitodiskurssin valossa kuten esimerkissä 2 . 
Kirjoittamisen arvioinnissa taito korostuu. Peruskoulun päättövaiheen oppimistulosten arviointi painottaa taitoa (Harjunen-Rautopuro 2015, 29), ja diskurssi on vahva myös ylioppilaskokeessa (Erra-Svinhufvud 2017, 324-327), joka luo käytänteitä lukion arkeen ja jossa "opettaja osoittaa virheet alleviivauksin" (YTL 2012, 11). Tästä syystä opiskelijat saattavat ehkä ajatella, että vaikeinta kirjoittamisessa on oikeinkirjoitus tai kielioppi, ja myös tekstien hiominen saattaa kohdistua kielen tasoon (Ranta 2007, 87-116). Ylioppilaskokeen arviointiperusteissa rakentuva hierarkia (Erra-Svinhufvud 2017, 338-341) kuitenkin osoittaa taitodiskurssin ilmentävän pikemminkin sitä kirjoittamista, mitä vähimmillään pitäisi osata. Kallionpään $(2017,194-195)$ mukaan taitodiskurssi ei sovellukaan uusien kirjoitustaitojen lähtökohdaksi, ja Barton (2007, 161-163) esittää, että se pitää yllä rajoittunutta käsitystä kirjoittamisesta.

Taitodiskurssi rakentaa mallia kirjoittajasta, joka hallitsee kieliopin ja oikeinkirjoituksen säännöt. Monet opiskelijat hahmottavat tämän tavoitteeksi, mutta kaikki eivät kuitenkaan omaksu diskurssin tarjoamaa subjektipositiota (ks. Burgess-Ivanič 2010, 236-237; Ivanič 1998, 27-29). Esimerkissä 3 kirjoittaja tuntuu pitävän todellisena kirjoittamisena jotakin muuta kuin taitodiskurssin mukaista tekstausta, kaunokirjoitusta ja kielioppia (Ivanič 2004, 227-229):

(3) Näin aluksi on pakko todeta, että amatöörihän minä olen. Kyllä, amatööri olen vaikka kirjoittamaan ne minut ja ikätoverini laittoivat jo ensimmäisellä luokka-asteella. Tekstausta opettivat. Kaunokirjoitusta opetettiin kai seuraavana vuonna; varmaa tietoa en osaa sanoa kun ei muisti riitä moiseen. Äidinkielen osalta se peruskoulu oli hyvin pitkälti sitä pelkkää kielioppia. Ei siitä osannut innostua. Mutta lukiossa kun ollaan keskitytty itse kirjoittamiseen niin on siitä mielenkiintoisempaa tullut. (06/19)

Opiskelija käsittelee kirjoittamisen oppimista puheenomaisesti, mitä ilmentää esimerkiksi artikkelimainen se-pronominin käyttö (VISK, $\$ 1418$ ). Kirjoittamisen opettajiin hän viittaa ensin pronominilla ne, jolla ei ole tekstissä korrelaattia. Opettajat ovat etäisiä toimijoita ja oppilaat toiminnan kohteita. Kirjoittaja käyttää nollapersoonalausetta käsitellessään kokemustaan peruskoulun äidinkielenopetuksesta ja tuntuu tarjoavan kokijan paikkaa lukijalle: hän ei itse osannut innostua, mutta ehkäpä lukija tai kukaan muukaan ei olisi vastaavassa tilanteessa osannut (VISK $\$ 1348$ ). Katkelman lopussa rakentuu vastakkainasettelu, joka syntyy kontrastiivisten mutta-konjunktion ja itse-sanan avulla (VISK $\S 1101 ; \$ 768)$. Mutta-lauseessa opiskelija ilmaisee, että itse kirjoittaminen, siis lukiossa opiskeltava kirjoittaminen, on muuta kuin kielioppia.

\subsection{Luovuusdiskurssi lukiolaisten kirjoitelmissa}

Ajatus, että tietynlainen kirjoittaminen on oikeampaa tai todempaa kuin toinen, saattaa liittyä taitodiskurssista voimakkaasti eroavaan luovuusdiskurssiin. Diskurssin mukaan kirjoittaminen on itsessään arvokasta, ja usein tekstien aiheet liittyvät kirjoittajien omiin 
kokemuksiin. Hyvän kirjoittamisen kriteerit tulevat kaunokirjallisuudesta, ja oppiminen on implisiittistä: kirjoittamalla paljon ja lukemalla hyviä tekstejä tulee paremmaksi kirjoittajaksi. Arviointi perustuu vaikuttavuuteen ja kiinnostavuuteen. (Ivanič 2004, 229230.) Luovuusdiskurssiin nojataan lähes kaikissa aineistoni kirjoitelmissa. Opiskelijoiden teksteissä diskurssi ilmenee omaperäisyyden tai itseilmaisun käsittelynä sekä viittauksina kaunokirjallisiin tekstilajeihin (esimerkki 4). Luova kirjoittaminen voi tuntua ainoalta todelliselta kirjoittamiselta, jota ilman kirjoittaja ei ole oikeastaan "kirjoittaja" (5):

(4) Tykkään kirjoittaa luovasti, mutta en tykkää tarkkailla kielioppisääntöjä. Kirjoittaminen olisi koulussa kivempaa jos saisi enemmän pisteitä siitä onko teksti hienoa ja luovaa eikä siitä onko pilkut ja pisteet paikoillaan. Kirjoittaminen on mielestäni hyvä tapa ilmaista itseään ja opin myös hyvin kirjoittamalla. En kuitenkaan aina jaksaisi kirjoittaa, sillä jos aihe ei ole mieluinen voi kirjoittaminen tuntua puuduttavalta. Tykkään kirjoittaa myös tekstitaitoa, mutta esseet joissa saa käyttää luovuutta tuntuvat miellyttävimmiltä. (15/43)

(5) Fiktiivistä kitrjoittamista [sic] ei juurikaan enää koulussa harjoiteta, mikä on sääli. Varmaankin sen takia en edes oikein tiedä millainen olen kirjoittajana. $(14 / 34)$

Toisinaan opiskelijat tarkastelevat koulun kirjoittamista pohtimalla, mikä olisi itselle miellyttävää, kuten esimerkissä 4. Tämä voi liittyä tehtävänantoon, joka ohjaa huomion kirjoittajaan itseensä, mutta kyse on myös luovuusdiskurssista, jossa arvostetaan itseä kiinnostavia aiheita. Tulkintaa tukee kieliopin ja luovuuden välinen vastakkainasettelu, joka rakentuu mutta-lauseen avulla heti katkelman alussa. Luovuusdiskurssista kielivät myös kirjoittamisen määritteleminen ilmaisuksi sekä ajatus sen oppimisesta kirjoittamalla. Esimerkeissä 4 ja 5 on merkittävä ero: ensimmäisessä diskurssi on relevantti koulussa, sillä kirjoittajan mukaan luovuutta tarvitaan esseekirjoittamisessa, kun taas toisessa luovuusdiskurssi ei liity kouluun, jossa fiktiivisiä tekstejä ei kirjoiteta. Esimerkin 4 kirjoittajan käsitys on lähempänä ylioppilaskokeen käsitystä (Erra-Svinhufvud 2017, 328-329).

Luovuusdiskurssi näkyy aineistossani selvästi muita diskursseja voimakkaammin. Tähän voi vaikuttaa peruskoulu, jossa luovalla diskurssilla on ollut melko vahva jalansija (ks. Pentikäinen-Routarinne-Hankala-Harjunen-Kauppinen, M.-Kulju 2017, 163-164), vaikkei se olekaan ainakaan nykyisin arvioinnin keskiössä (Harjunen-Rautopuro 2015, 29). Lukiolaiset tukeutuvat luovuusdiskurssiin opetussuunnitelmia ja ylioppilaskoetta enemmän (Erra-Svinhufvud 2017, 327-329). Myös ruotsalaisessa tutkimuksessa (Randahl 2011) luovuusdiskurssi oli vahva lukioikäisten keskuudessa silloinkin, kun opetus painotti muita näkökulmia. 


\subsection{Prosessidiskurssi lukiolaisten kirjoitelmissa}

Prosessikirjoittamisen teoria perustuu kirjoittamisen tutkimukseen ja korostaa kirjoittajan kognitiivista prosessia sekä käytännöllisiä työprosesseja, kuten suunnittelua, muokkausta ja tarkistusta (Flower-Hayes 1981). Prosessidiskurssiin kuuluvat viittaukset kirjoittamisen vaiheisiin tai toimintatapoihin, kuten yhteistyöhön, vertaispalautteeseen ja pienryhmätyöskentelyyn (Ivanič 2004, 231-232). Prosessikirjoittamisen merkitys näkyy aineistossani esimerkiksi aloittamisen tai muokkaamisen käsittelynä, mutta opiskelijat eivät yleensä itse käytä diskurssia, vaan tekstejä analysoiva tutkija tai opettaja huomaa tarkastelun liittyvän prosessiin. Näin on esimerkissä 6, jossa ideoiden runsas määrä tekee teksteistä jäsentymättömiä:

(6) Tekstitaidot ja esseet on välillä hankalia lähinnä, koska niiden erottaminen ja "viralliset" säännöt ovat hankalia nekä [sic] tahdo muistaa niitä. Kirjoitaessani [sic] helposti hypin asioista toiseen, koska mielessä pyörii ideoita välillä liikaa. Tämän takia välillä keksin lisää ideoita tekstiin jälkikäteen. (14/32)

Esimerkin alussa kirjoittaja kuvaa koulun tekstilajeihin liittyviä vaikeuksia: sana hankala, joka tässä merkitsee 'vaikeasti tehtävää' tai 'vaivalloista', toistuu (KS s.v. hankala). Seuraavaksi täsmentyy, mikä kirjoittamisesta tekee vaikeaa. Lukiolainen kuvaa kirjoittamista eikä lopputulosta, mutta tuotetun tekstin voi päätellä olevan epäkoherentti. Ratkaisu löytyisi kenties suunnittelemisesta ja muokkaamisesta. Moni lukiolainen kertoo teksteihin jäävistä sisällöllisistä ja kielellisistä virheistä, mutta harva kertoo muokkaavansa tekstejään. Näin on siitä huolimatta, että kirjoitusprosessi on kuulunut myös peruskoulun opetussuunnitelmiin (Murtorinne 2005) ja kaikki tutkimukseen osallistuneet olivat siinä vaiheessa opintoja, että sitä oli käsitelty ainakin lukion ÄI2-kurssilla.

Erilaisista vaiheista koostuva kirjoittamisprosessi ei siis juurikaan näy opiskelijoiden teksteissä, mutta aineistossa on yksittäisiä esimerkkejä tekstin suunnittelusta, luonnostelusta ja muokkaamisesta, ja yleensä opiskelijat tuovat esiin, etteivät he osaa tai halua suunnitella tai muokata tekstejään (myös Ranta 2007). Prosessikirjoittamisen diskurssi ei siis kovinkaan usein tarjoa lukiolaisille subjektipositiota, johon asettua. Esimerkin 7 kirjoittaja kuitenkin kertoo suunnittelevansa tekstejään ajatuskartan avulla, ja esimerkin 8 viimeisessä virkkeessä kirjoittaja ilmaisee, että tekstin suunnittelu olisi tarpeen:

(7) Tämä teksti ei välttämättä ole hirveän johdonmukainen, eikä varmaan tarvitsekaan, mutta yleensä teen ajatuskartan, jonka mukaan on helppo kirjoittaa, kun kirjoittaa karttaan asiat, jotka kirjoitelmaan haluaa ja miettii rakenteen. Ennen lukiota en tätä käyttänyt, mutta voin sanoa, että arvosanani olisivat huonommat ilman, tosin kaikki eivät tykkää. (06/20)

(8) Kirjoittaminen on hauskaa kun pääsee kunnolla vauhtiin, mutta minulla kestää aina kauan ennen kuin keksin mitä kirjoitan. Useasti jos vaikkapa kirjoitetaan kuva-analyysia tai novellianalyysia keksin hyvin mitä kirjoita [sic], mutta 
sitten kun olen kirjoittanut puolet tekstistä huomaan, että välistä puuttuu jotain enkä tietenkään jaksa kumittaa kaikkea vaan jätän sen sellaiseksi kuin se on ja saan huonon numeron. Minun pitäisi miettiä tarkemmin mitä kirjoitan ennen kun aloitan kirjoittamaan. (06/14)

Esimerkissä 7 kirjoittaja esittää kielteisen arvion tutkimusta varten kirjoittamastaan tekstistä ja vihjaa, että epäjohdonmukaisuus johtuu suunnittelemattomuudesta. Kontrastiivisella mutta-lauseella kirjoittaja erottaa kirjoitustilanteen tavanomaisesta, ja kenties hän pitää ajatuskartan avulla kirjoitettuja tekstejään johdonmukaisina. Esimerkissä 8 opiskelija kuvaa kirjoitustilannetta, joka ei pääty hyvin. Katkelman viimeisessä virkkeessä opiskelija evaluoi kertomaansa ja tuo esiin, että miettiminen eli tekstin suunnittelu saattaisi tuottaa paremman lopputuloksen.

Vaikka aineistossani on jonkin verran viitteitä prosessidiskurssista, ei kirjoittaminen näytä koostuvan erilaisista vaiheista. Kirjoittamiseen ei liity tekstin kehittäminen enää palautteen jälkeen, ja vain harvat kertovat tekstin suunnittelusta. Tämä on kiinnostavaa, sillä prosessidiskurssi on kuitenkin hyvin täsmällisesti läsnä lukion opetussuunnitelmassa (Erra-Svinhufvud 2017, 329-330; Ranta 2007, 278-279). Ristiriidan syitä voi etsiä mm. arvioinnista, sillä ylioppilaskokeen arviointiperusteissa diskurssi ei näy (Erra-Svinhufvud 2017, 329-330).

\subsection{Genrediskurssi lukiolaisten kirjoitelmissa}

Genrediskurssi näkee kirjoittamisen tekstilajin tuottamisena ja korostaa tekstien lingvistisiä eroja, joihin tarkoitus ja konteksti vaikuttavat. Kirjoitettaessa tekstilajien ominaispiirteet voivat olla tekstin sisältöä tärkeämpiä. Oppiminen on osin implisiittistä, mutta tekstilajien käytänteitä myös opetetaan esimerkiksi mallien ja tekstien ominaisuuksien kuvaamiseen tarvittavien kielitieteellisten käsitteiden avulla. (Ivanič 2004, 232-234.) Aineistossani genrediskurssi ilmenee tekstilajien luettelemisena, ja siihen on jonkinlaisia viittauksia noin kolmanneksessa teksteistä. Esimerkissä 9 lukiolainen käsittelee todennäköisesti omaa kokemustaan lukion kirjoittamisesta ja tekstilajien vaativuudesta, ja esimerkissä 10 käsittely liikkuu enemmän yleisellä tasolla, vaikka kirjoittaja viittaa myös itseensä:

(9) Arvosteluja ja analyysejä ja referaatteja on suhteellisen helppo tehdä, koska niihin on hyvät ohjeet ja tietyt jutut mitä niihin täytyy laittaa. $(06 / 16)$

(10) Kirjoittaminen on tekstien tuottamista. Siihen törmää joka päivä erilaisissa yhteyksissä. Nykyään ihmiset kirjoittavat eniten netissä, jossa on helppo jakaa omia mielipiteitään erilaisten kanavien kautta. Itse kirjoitan paljon tilannepäivityksiä netissä. Erilaisia tekstilajeja voivat olla kauno, ja tieteelliset tekstit. Myös koulussa kirjoitetaan paljon, esimerkiksi esseetekstejä ja tekstitaitoa. (14/29)

Esimerkissä 9 opiskelija liittää helppouden tiettyihin tekstilajeihin ja kuvaa kirjoittamista genrediskurssin mukaisesti ohjeiden noudattamisena. Hän tuntuu käsittelevän omaa 
kokemustaan, mutta ilmaisee kokemuksen nollapersoonan avulla ja tarjoaa näin kokijan paikkaa myös lukijalle (VISK \$ 1348). Esimerkissä 10 ensimmäinen virke määrittelee kirjoittamisen tekstien tuottamiseksi, minkä jälkeen huomio kiinnittyy erilaisiin kirjoittamisympäristöihin ja tekstilajeihin. Kirjoittaminen näyttäytyykin sekä tekstien että lajien tuottamisena. Katkelman lopussa lukiolainen siirtää huomion kouluympäristöön ja lisää luetteloonsa koulun tekstilajeja. Aiemmin mainitut lajit eivät välttämättä liitykään kouluun, sillä niitä kirjoittavat ihmiset, joka on lukiolaisia laajempi ryhmä.

Myöskään genrediskurssi ei ilmene opiskelijoiden teksteissä yhtä voimakkaasti kuin taito- ja luovuusdiskurssit. Tämä voi johtua osin siitä, että Ivaničin mallissa se hahmottuu muun muassa erilaisten käsitteiden käyttönä (Ivanič 2004, 232-234), johon opiskelijat eivät opinnoistaan huolimatta ole välttämättä kovin harjaantuneita. Toisaalta esimerkiksi tekstilajeista puhuminen saattaa nostaa käsittelyn yleiselle tasolle, jolloin oma kokemus kenties etääntyy (Mason 2002, 230). Näin on esimerkissä 10, jossa kirjoittaja määrittelee kirjoittamista ja puhuu yleisesti ihmisistä ennen kuin siirtyy omaan kirjoittamiseensa.

Selvimmin genrediskurssi ilmeneekin vuoden 2014 aineistossa. Kyse voi olla koulu- ja opettajakohtaisista eroista, mutta koska suomalainen koulumaailma on varsin yhtenäinen (Kauppinen, A. 2011, 358-359), on perusteltua pohtia tehtävänantojen vaikutusta. Toin aiemmin esiin, että vuoden 2014 aineistossa kirjoittamista käsitellään myös hyvin yleisellä tasolla. Genrediskurssi tuntuukin korostuvan kirjoittamista määritellessä. Kenties se ei tarjoudu oman kirjoittamisen pohtimiseen yhtä hyvin kuin taito- ja luovuusdiskurssit siitäkään huolimatta, että nämä kaikki keskittyvät tekstituotokseen esimerkiksi kirjoittamisen kontekstin sijaan (vrt. Randahl 2011).

\subsection{Sosiaalisten käytänteiden diskurssi lukiolaisten kirjoitelmissa}

Sosiaalisten käytänteiden diskurssissa tekstit ja kirjoittamisprosessit liittyvät vuorovaikutukseen ja kirjoittamisen sosiaaliset tavoitteet ovat tärkeitä. Diskurssi ei aseta etusijalle koulukirjoittamista, ja kirjoittamista opitaan sosiaalistumalla. Oppiminen ei kohdistu vain tekstin rakentamiseen, vaan se ulottuu sosiaaliseen kontekstiin, kuten erilaisiin kirjoittamisen olosuhteisiin. Arviointi painottaa sosiaalisten päämäärien saavuttamista. (Ivanič 2004, 234-237.) Aineistossani sosiaaliset tavoitteet, kuten ymmärtäminen tai vuorovaikutus, ovat usein jollakin tapaa ristiriidassa muiden tavoitteiden kanssa:

(11) Tavallisesti saatan kyllä eksyä pahasti kirjoittamaan ihan puhekielellä, sen huomaa joistakin aineista esimerkiksi. Mutta kunhan siitä saa selvää. (06/12)

(12) Olen luultavasti aika tylsä kirjoittaja. Kirjoitan harvoin milläänlailla luovaa tekstiä ja suurin osa tuottamastani tekstistä syntyykin WhatsApp-viestien muodossa tai sähköposteina. Kirjoittamiseni on siis suurimmilta osin suoraa kanssakäymistä muiden kanssa eivätkä yksittäiset viestit ole kovinkaan pitkiä. $(14 / 34)$ 
Esimerkin 11 kirjoittaja kuvaa puhekielisyyttä käyttäen eksyä-verbiä, joka merkitsee 'harhautumista' (KS s.v. eksyä). Tämä implikoi kirjoittajan pitävän puhekielellä kirjoittamista epätoivottuna, ja tulkintaa vahvistavat adverbi pahasti ja partikkeli ihan. Aineen tekstilaji kontekstualisoi tilanteen kouluun. Rinnastuskonjunktio mutta aloittaa kontrastiivisen lauseen, joka näyttäytyy eräänlaisena selityksenä tai puolustuksena ja synnyttää ristiriidan: vaikka puhekielisyys on hairahdus, on ymmärtäminen kirjakielisyyttä tärkeämpää. Esimerkissä 12 kirjoittaja esittää itsestään väitteen, jota perustelee seuraavissa tukivirkkeissä. Lukiolainen kertoo kirjoittavansa ollakseen vuorovaikutuksessa toisten kanssa, eikä pidä tekstejään luovina. Syntyy vaikutelma, että sosiaalisten tavoitteiden saavuttaminen on ristiriidassa luovuuden kanssa, ja tekstien lyhyyskin näyttäytyy kielteisessä valossa, vaikka todellisuudessa monissa kirjoitustilanteissa tavoitellaan napakkaa ja tiivistä ilmaisua.

Sosiaalisten käytänteiden diskurssi ei tunnukaan liittyvän aineistossa kouluun. Tulos on samansuuntainen kuin opetusta ohjaavien dokumenttien analyysissä (Erra-Svinhufvud 2017), ja sitä voi pitää osin odotuksenmukaisena, ainakin kirjoittamiseen liittyvän arvioinnin näkökulmasta. On kuitenkin keskeistä huomata, että jos koulussa sivuutetaan vapaa-ajan kirjoittamista, saatetaan sivuuttaa toimintaa, joka olisi opiskelijoille merkityksellistä ja motivoivaa (Kallionpää 2014, 273; Kauppinen, A. 2011; Lillis 2013, 75-77).

Myös kirjoittamiskulttuurin yksinäisyys (esim. Erra 2018; Harjunen-Rautopuro 2015) tulee esiin diskurssien analyysissa. Kuvatessaan kirjoittamista lukiolaiset eivät juuri kuvaa toimintaa, johon muut ihmiset osallistuvat, eivätkä he näe itseään osana kirjoittavia ryhmiä (ks. Ivanič 2004, 234-237). Yhdessä kirjoittamiseen harjaantuminen voi kuitenkin olla hyödyllistä niin jatko-opintojen kuin työelämänkin kannalta. Vaikka yksinäisyyden ja yksilöllisyyden vahva asema on yksilösuorituksiin keskittyvän arvioinnin näkökulmasta odotuksenmukainen, voisi koulussa olla tilaa myös yhteiskirjoittamiselle. Peruskoulun opetussuunnitelmissa on korostettu paljon yhteistyötä ja yhteisöllisyyttä (Murtorinne 2005, 21), ja yhteistyötä painotetaan myös lukion opetussuunnitelmassa (LOPS 2003; 2015). Jos toiminta on yksinäistä, ei oppiminen ole yhteisöllistä.

\subsection{Sosiopoliittinen diskurssi lukiolaisten kirjoitelmissa}

Sosiopoliittinen diskurssi on osin päällekkäinen sosiaalisten käytänteiden diskurssin kanssa, koska molemmat korostavat kirjoittamisen kontekstin merkitystä. Sosiopoliittinen konteksti on kuitenkin laajempi, sillä se huomioi myös valtasuhteet: kirjoittaja hyödyntää sekä diskursseja, jotka esittävät maailman tietyillä tavoilla, että lajeja, jotka ovat tietynlaisen sosiaalisen vuorovaikutuksen käytänteitä. Kirjoittamisen oppiminen on kielellisten valintojen tarkastelua sekä tietoisuutta valtarakenteista, jotka ohjaavat kirjoittajaa. (Ivanič 2004, 237-240.)

Aineistossani sosiopoliittinen diskurssi on kaikista vähiten esillä. Esimerkissä 10 lukiolainen tuo esiin, että ihmiset voivat jakaa mielipiteitään kirjoittamalla. Jakaa-verbi merkitsee tässä 'antamista' tai 'osallistumista' (KS s.v. jakaa), ja koska subjekti on monikollinen ihmiset, voi toimintaan tulkita liittyvän vastavuoroisuutta. Kirjoittaja ei kuitenkaan 
puhu omasta toiminnastaan tai kirjoittamisesta koulussa vaan käsittelee aihetta yleisesti. Sen sijaan esimerkin 13 kirjoittaja on omaksunut diskurssin siinä mittakaavassa kuin sen voi lukiossa ylipäänsä odottaa toteutuvan (ks. Erra-Svinhufvud 2017):

(13) Kirjoittamisen osaaminen on tärkeää, koska esimerkiksi mielipidekirjoituksien vakuuttavuus riippuu paljon siitä, miten ne ovat kirjoitettu. Asiallisesti muotoillut ja perustellut argumentit ovat tehokkaampia muuttamaan lukijan ajatuksia, kuin pelkkä omien mielipiteiden kertominen ja "olen oikeassa, muut väärässä”- asenne. $(14 / 28)$

Kirjoittaja tarkastelee tekstien vakuuttavuutta ja argumentointia sekä perustelee niillä kirjoittamisen osaamisen arvoa. Osaamisen käsittely vihjaa, että kirjoittamista pohditaan koulukontekstissa. Lukiolainen tarkastelee aihetta etäältä ja yleisesti, mutta ei ainakaan sulje pois mahdollisuuksiaan vaikuttaa kirjoittamalla.

Kirjoitelma-aineistossa ei käsitellä lainkaan eettisiä kysymyksiä ja kirjoittajan omaa vastuuta, vaikka ne tulevat esiin opetussuunnitelman perusteiden oppiaineita yhdistävissä aihekokonaisuuksissa (Erra-Svinhufvud 2017, 335). Tämä voi kieliä siitä, etteivät opiskelijat pidä näkökulmaa kirjoittamisen kannalta keskeisenä, tai siitä, että he eivät hahmota itseään sellaisina toimijoina, joiden valinnoilla olisi merkitystä.

\section{Lopuksi: tavoitteeksi kokonaisvaltainen kirjoittamisen opetus}

Tässä artikkelissa pyrin Ivaničin viitekehykseen tukeutuen selvittämään, mitä kirjoittamisen diskursseja lukiolaisten tekstit kaiuttavat. Valmiin mallin käyttämiseen liittyy rajoituksia. Vapaampi analyysi olisi ehkä auttanut löytämään myös muita diskursseja, mutta toisaalta valittu lähestymistapa mahdollistaa tulosten vertailun muihin tutkimuksiin ja näyttää, mitkä diskurssit ovat vain heikosti edustettuna. Ivaničin malli ei ole ongelmaton kuvaus kirjoittamisen diskursseista, sillä genrediskurssi ja sosiaalisten käytänteiden diskurssi ovat nykyisin ainakin osin päällekkäisiä (Erra-Svinhufvud 2017, 321-322). Kirjoitelma-aineistossa ne kuitenkin näyttäytyvät erillisinä käsitteellistyksinä, minkä vuoksi niitä voi olla hyödyllistä tarkastella myös jatkossa omina näkökulminaan.

Aineistossani diskurssit painottuvat eri tavalla kuin opetusta ohjaavissa dokumenteissa. Lukiolaisten tekstejä dominoivat taito- ja luovuusdiskurssi, jotka ovat osin vastakkaisia näkemyksiä. Genrediskurssi on jossain määrin edustettuna, ja kirjoittamisen prosessia sekä sen sosiaalisuutta tai sosiopoliittisuutta käsitellään varsin vähän. Opetussuunnitelmat sen sijaan painottavat eri asioita: niissä kirjoittaminen hahmottuu jonkin verran taitona tai prosessina ja hyvin usein tekstilajin tuottamisena. Opetussuunnitelmissa taitodiskurssi vaikuttaa ennen kaikkea taustalla eikä tule selvästi esiin yksittäisten kurssien sisällöissä ja tavoitteissa. Luovuusdiskurssiin on vain yksittäisiä viittauksia. Ylioppilaskokeen määräyksissä taas painotetaan taito- ja genrediskursseja, ja kirjoittamisen prosessiin tai sosiaalisuuteen liittyvät seikat eivät näyttäydy. Luovuusdiskurssi ja sosiopoliittinen 
diskurssi näkyvät vain vähän, lähinnä arviointiperusteiden parhaiden tekstien kuvauksissa. (Erra-Svinhufvud 2017.) Kirjoitetut opetussuunnitelmat näyttävätkin olevan ikään kuin ideaaleja, joista vain osa toteutuu koulussa kunnolla (esim. Remillard-Heck 2014). Toki on huomattava, että tutkimukseen osallistuessaan aineiston kirjoittajat ovat olleet eri vaiheissa opintojaan ja esimerkiksi ylioppilaskirjoitusten jälkeen olisi voinut nousta esiin toisenlaisia näkökulmia.

Ivanič (2004, 240-242) suosittelee opetukseen kirjoittamisen kokonaisvaltaisuutta, joka merkitsee kaikkien kirjoittamisen diskurssien sekä tekstin, kirjoitustilanteen, prosessin ja sosiokulttuurisen kontekstin vaikutuksen huomioimista (myös esim. Peterson ym. 2018; Randahl 2011; Svinhufvud 2016). Tutkimukseni valossa kokonaisvaltaisuuden tavoittelu voikin olla hyvä lähtökohta lukion kirjoittamisen opettamisen kehittämiselle. Opetuksen perustana voi pitää taitodiskurssia, joka on aineistossani varsin vahva. Taitoon keskittyvää kirjoittamista on kritisoitu (Kallionpää 2014), mutta aineistossani se näyttäytyy myös myönteisessä valossa kenties konkreettisuutensa vuoksi. Ylioppilaskokeessa taitodiskurssi ilmentää sitä osaa kirjoittamisesta, joka on vähimmillään osattava (Erra-Svinhufvud 2017, 338-341). Sääntöjen ja kieliopin opiskelu onkin edelleen hyödyllistä myös lukiotasolla, mutta on muistettava, että kyseessä on vain yksi osa kirjoittamista ja taitavien tekstintekijöiden osaaminen on monipuolisempaa (Erra-Svinhufvud 2017; Ranta 2007).

Luovuusdiskurssi on aineistossani niin voimakas, että lähes kaikki kirjoitelmat nojaavat siihen, vaikka opetussuunnitelmissa ja ylioppilaskokeessa sitä ei painoteta (Erra-Svinhufvud 2017). Kyse voi olla institutionaalista kontekstia laajemman sosiokulttuurisen ympäristön vaikutuksesta lukiolaisten ajatteluun. Myös Randahlin (2011) aineistossa luovuusdiskurssi kukoisti lukioikäisten käsityksissä, vaikka opetus ei sitä korostanut. Näyttääkin siltä, että opiskelijoilla on käytössään enemmän diskursseja kuin opettajat opetuksessaan painottavat (mts. 100). Luovuusdiskurssi on niin voimakas, ettei sitä mielestäni voi lukiossa täysin sivuuttaa. Jos opetuksen tavoitteet ovat ristiriidassa opiskelijoiden käsitysten kanssa, on asiaa puitava oppitunneilla. Toisaalta luovan kirjoittamisen menetelmiä kannattaa hyödyntää myös asiatekstien kirjoittamisessa (Hesse 2010; Juutinen 2004).

Merkille pantavaa aineistossani on opiskelijoiden etäinen suhde prosessikirjoittamiseen (vrt. Randahl 2011). Prosessidiskurssi on täsmällisesti läsnä opetussuunnitelmissa mutta ei käytännössä lainkaan ylioppilaskokeen määräyksissä (Erra-Svinhufvud 2017). Tämä epäsuhta selittyy sillä, että kirjoittamisen arviointi kohdistuu tekstiin eikä prosessiin. Aineistoni perusteella näyttää siltä, etteivät monet lukiolaiset joko halua tai osaa suunnitella ja muokata tekstejään. Myöskään prosessikirjoittamiseen liittyvät työtavat kuten yhteistyö tai vertaisarviointi (Ivanič 2004, 232) eivät näy aineistossani. Tulos tukee Rannan (2007) tutkimusta, jonka mukaan lukiolaiset ovat varsin taitamattomia tekstin muokkaajia vielä juuri ennen ylioppilaskoetta. Voisiko syytä etsiä lukion tiukasta aikataulusta? Kirjoittamisen prosessia käsitellään kahdella pakollisella kurssilla (Erra-Svinhufvud 2017, 329-330; LOPS 2015, 42-46), mutta onko lukion arjessa aikaa suunnitella tekstejä ja muokata niitä palautteen perusteella? Oppiminen edellyttää toistoa, joten myös 
erilaisten kirjoittamisen vaiheiden pitäisi olla melko jatkuvasti läsnä kirjoittamista opiskellessa.

Sekä opetussuunnitelmat että ylioppilaskoe painottavat genrediskurssia (Erra-Svinhufvud 2017), ja myös aineistossani kirjoittaminen on toisinaan tekstilajin tuottamista. Kirjoittamisen sosiaalisuuden ja sosiopoliittisuuden vähäisyys on linjassa opetussuunnitelmien ja ylioppilaskokeen kanssa (mp.). Kirjoittamisen sosiaaliset tavoitteet voivat toisinaan asettua ristiriitaan muiden tavoitteiden kanssa. Oppimisen kannalta voi olla tärkeää pohtia, miksi kirjoittamisella on koulussa muitakin tavoitteita kuin ymmärretyksi tuleminen tai mihin ymmärrettävyys erilaisissa konteksteissa perustuu. Kirjoittamisen merkitys voi laajentua, jos se nähdään yhä useammin myös vaikuttamisena tai osallistumisena sosiaaliseen toimintaan (ks. Kallionpää 2017). Tähän suuntaan ollaankin menossa, sillä opetussuunnitelman perusteissa painotetaan yhä enemmän osallisuutta ja vuorovaikutusta niin koulun sisällä kuin yhteiskunnassakin (LOPS 2015, 16).

Lukion kirjoittamisen opetukseen liittyvät uudistukset tarjoavat tilaisuuden huomioida entistä enemmän ympäristön vaikutusta kirjoittamiskäsityksiin. Voi olla hyödyllistä, että niin opetuksen kehittäjille, oppimateriaalien tekijöille, opettajille kuin opiskelijoillekin järjestetään tilaa ja aikaa pohtia, mistä oikeastaan puhumme, kun puhumme kirjoittamisesta, ja onko meille selvää, mitä kulloinkin opiskellaan ja arvioidaan. Kirjoittamisesta sekä siihen liittyvistä tavoitteista ja mielikuvista keskusteleminen voivat olla tärkeä osa oppimista. Käytännössä tämä tarkoittaa, että joitakin muita oppiaineen sisältöjä täytyy karsia tai kurssimäärää lisätä.

Kokonaisvaltaisen kirjoittamisen pedagogiikka edellyttäisi joidenkin kirjoittamisen diskurssien vahvistamista lukiossa. Prosessin harjoittelemiselle olisi kenties järjestettävä aikaa, mutta toisaalta opiskelijat tarvitsevat myös kielioppia ja oikeinkirjoituksen taitoja. Opiskelijoiden luovuusdiskurssia kaiuttavat käsitykset olisi hyvä huomioida, etenkin jos ne ovat ristiriidassa lukioinstituution painottamien diskurssien kanssa. Vapaa-ajan sosiaalisten käytänteiden arvon tunnustaminen saattaisi parantaa joidenkin opiskelijoiden motivaatiota. Sosiaalisen median aikakaudella on tärkeää huomioida myös sosiopoliittisia seikkoja. Miten opiskelijoille taattaisiin mahdollisuus osallistua? Miten opiskelijoilla olisi kirjoittajina todellista valtaa? Miten opiskelijoiden kynien ja näppäimistöjen ääni saataisiin paremmin kuuluviin, eikä vain kuuluviin vaan osaksi kirjallista keskustelua, osalliseksi? Nämä näkökulmat tulisi huomioida opetussuunnitelmauudistuksessa, oppikirjatyössä sekä täydennyskoulutuksessa.

\section{Lähteet}

Barton, David 2007 [1994]: Literacy. An introduction to the ecology of written language. Toinen painos. Blackwell, Malden

Burgess, Amy 2012: "I don't want to become a China Buff": Temporal dimensions of the discoursal construction of writer identity. Linguistics and Education 23, 223-234. https://doi.org/10.1016/j. linged.2012.04.001

Burgess, AMY - IvAnIČ, Roz 2010: Writing and being written: Issues of identity across timescales. Written 
Communication 27 (2), 228-255. Sage, London. https://doi.org/10.1177\%2F0741088310363447

Cameron, Deborah 2005: Language, gender, and sexuality. Applied Linguistics 26 (4), 482-502. British Association for Applied Linguistics - International Association for Applied Linguistics, Oxford. https://doi.org/10.1093/applin/amio27

ERRA, SATU 2018: Kirjoittamisen tarjoumat lukiossa. Scriptum creative writing journal 5 (1), 47-94. Jyväskylän yliopisto, Jyväskylä. http://www.urn.fi/URN:NBN:fi:jyu-201801091111

Erra, Satu - Svinhufvud, Kimmo 2017: Kirjoittamisen diskurssit lukion opetussuunnitelman perusteissa ja ylioppilaskokeen määräyksissä. Virittäjä 121 (3), 316-354. https://doi.org/10.23982/ vir. 51462

Eskola, JaRI - Suoranta, Juha 1998: Johdatus laadulliseen tutkimukseen. E-kirja. Vastapaino, Tampere

Flower, Linda - HaYes, John R. 1981: A cognitive process theory of writing. College Composition and Communication 32 (4), 365-387. National Council of Teachers of English, Urbana. https://doi. org/10.2307/356600

Gee, James Paul 2008: Social linguistics and literacies. Ideology in discourses. Kolmas painos. Routledge, London. https://doi.org/10.4324/9780203944806

2014: An introduction to discourse analysis. Theory and method. Neljäs painos. Routledge, London.

GrÜNN, KARL 2007: Tekstitaidot kirjallisuuden opetuksen suuntaajina. SATU GRÜNTHAL ja ElINA HARJUNEN (toim.): Näköaloja äidinkieleen ja kirjallisuuteen, 107-122. Suomalaisen Kirjallisuuden Seura, Helsinki

HarJunen, Elina - Rautopuro, Juhani 2015: Kielenkäytön ajattelua ja ajattelun kielentämistä. Äidinkielen ja kirjallisuuden oppimistulokset perusopetuksen päättövaiheessa 2014: keskiössä kielentuntemus ja kirjoittaminen. Kansallinen koulutuksen arviointikeskus, Helsinki. Saatavissa https:// karvi.fi/publication/kielenkayton-ajattelua-ja-ajattelun-kielentamista/

Helttunen, ANne - Julin, Anita (toim.) 2008: Kiittäen hyväksytty. Äidinkielen ylioppilaskokeen historiaa ja nykypäivää. Äidinkielen opettajain liitto, Helsinki.

Hesse, Douglas 2010: The place of creative writing in composition studies. College Composition and Communication 62, 31-52. National Council of Teachers of English, Urbana.

Hyland, Ken 2002: Teaching and researching writing. Routledge, London.

IVANIČ, Roz 1998: Writing and identity. The discoursal construction of identity in academic writing. John Benjamins, Amsterdam. https://doi.org/10.1075/swll.5

2004: Discourses of writing and learning to write. Language and Education 18 (3), 220-245. Taylor \& Francis, London. https://doi.org/10.1080/09500780408666877.

Jones, Susan - Myhill, Debra 2007: Discourses of difference? Examining gender differences in linguistic characteristics of writing source. Canadian Journal of Education / Revue canadienne de léducation 30 (2), 456-482. Canadian Society for the Study of Education, Ottawa. https://doi. org/10.2307/20466646

Juhila, Kirsi 1999: Tutkijan positiot. ArJa Jokinen, Kirsi Juhila ja Eero Suoninen (toim.): Diskurssianalyysi liikkeessä, 201-232. Vastapaino, Tampere.

JuUtinen, JARI 2004: Asiakirjoittaminen vaatii luovuutta. Minna-RiItta LuUkKa ja PASI JäÄsKeläINEN (toim.): Hiiden hirveä hiihtämässä: Hirveä(n) ihana kirjoittamisen opetus, 69-78. ÄOL, Helsinki.

Juvonen, RittTa 2014: Kirjoitelma ja tekijän ääni. Kehystämisen yhdyslauseet suomenkielisen ylioppilasaineen dialogisuuden hallinnassa. Helsingin yliopisto, Helsinki. http://urn.fi/ URN:ISBN:978-951-51-0264-5

Juvonen, Rittta - Kauppinen, Anneli - Makkonen-Craig, Henna - Lehti-Eklund, Hanna 2011: Mitä lukiolaisten kirjoittamisesta on tutkittu? Anneli Kauppinen, Hanna Lehti-EkLund, Henna Makkonen-Craig ja Rittta Juvonen (toim.): Lukiolaisten äidinkieli. Suomen- ja ruotsinkielisten lukioiden opiskelijoiden tekstimaisemat ja kirjoitustaitojen arviointi, 27-61. Suomalaisen Kirjallisuuden Seura, Helsinki.

Kallionpä̈̈, OUti 2014: Upper secondary school graduates' attitudes toward writing. Hannu L. T. Heikkinen, Josephine Moate ja Marja-Kristiina Lerkkanen (toim.): Enabling education. Proceedings of the annual conference of Finnish Educational Research Association FERA 2013, 
259-286. FERA, Jyväskylä.

KallionpäÄ, OUti 2017: Uuden kirjoittamisen opetus. Osallistavaa luovuutta verkossa. Scriptum creative writing journal 1/2017. Jyväskylän yliopisto, Jyväskylä. http://urn.fi/ URN:NBN:fi:jyu-201701121134

Kauppinen, Anneli 2011: Lukiolaisten tekstimaisemat ja kieliasenteet - kyselytutkimuksen satoa. Anneli Kauppinen, Hanna lehti-Eklund, Henna Makkonen-Craig ja Riitta Juvonen (toim.): Lukiolaisten äidinkieli. Suomen- ja ruotsinkielisten lukioiden opiskelijoiden tekstimaisemat ja kirjoitustaitojen arviointi, 303-383. Suomalaisen Kirjallisuuden Seura, Helsinki.

KAUPPINEN, MERJA 2010: Lukemisen linjaukset. Lukutaito ja sen opetus perusopetuksen äidinkielen ja kirjallisuuden opetussuunnitelmassa. Jyväskylän yliopisto, Jyväskylä. http://urn.fi/ URN:NBN:fi:jyu-201701121134

Kauppinen, Merja - Pentikäinen, Johanna - Hankala, Mari - Kulju, Pirjo - Harjunen, Elina - RoutArinne, SARA 2015: Systemaattinen katsaus perusopetusikäisten kirjoittamisen opetusta ja osaamista koskevaan tutkimukseen. Kasvatus 46 (2), 160-175. FERA, Jyväskylä. http://urn.fi/ URN:NBN:fi:ELE-1754173

Kronholm-CeDerberg, AnNette 2009: Skolans responskultur som skriftpraktik. Gymnasisters berättelser om lärarens skriftliga respons på uppsatsen. Åbo Akademis Förlag, Åbo. http://urn.fi/ URN:ISBN:978-951-765-505-7

KS = Kielitoimiston sanakirja. 2018. Kotus, Helsinki. URN:NBN:fi:kotus-201433. Verkkojulkaisu HTML. Päivitettävä julkaisu. [Päivitetty 6.6.2018. Viitattu 22.1.2019.]

LILlis, Therese 2013: The sociolinguistics of writing. Edinburgh University Press, Edinburgh.

LOPS 2003 = OPETUSHALLITUS 2003: Lukion opetussuunnitelmien perusteet 2003. Opetushallitus, Helsinki.

LOPS 2015 = OPETUSHALlitus 2015: Lukion opetussuunnitelmien perusteet 2015. Opetushallitus, Helsinki.

McCarthey Sarah J. - Woodard, Rebecca - Kang, Grace 2014: Elementary teachers negotiating discourses in writing instruction. Written Communication 31 (1), 58-90. Sage, London. https:// doi.org/10.1177/0741088313510888

Mason, Jennifer 2002: Qualitative interviewing: asking, listening and interpreting. Tim MaY (toim.): Qualitative research in action, 225-241. Sage, London.

Murtorinne, Annamari 2005: Tuskan hauskaa! Tavoitteena tiedostava kirjoittaminen. Kirjoittamisprosessi peruskoulun yhdeksännellä luokalla. Jyväskylän yliopisto, Jyväskylä. http://urn.fi/ URN:ISBN:951-39-2258-8

Mäntynen, Anne - PietikÄInen, SARi 2009: Kurssi kohti diskurssia. Vastapaino, Tampere.

MikKonen, INKa 2010: "Olen sitä mieltä, että..." Lukiolaisten yleisönosastotekstien rakenne ja argumentointi. Jyväskylän yliopisto, Jyväskylä. http://urn.fi/URN:ISBN:978-951-39-3826-o

OJA, OUti 2018: Äidinkielen digitaalinen ylioppilaskoe kirjoitetaan ensimmäistä kertaa syksyllä 2018. Avain 1 (2018), 80-85. Kirjallisuudentutkijainseura, Oulu. https://doi.org/10.30665/av.70009

Pentikäinen, Johanna - Routarinne, Sara - Hankala, Mari - Harjunen, Elina - Kauppinen, MERJA - KulJU, PIRJO 2017: Oikeinkirjoituksesta monilukutaitoon: suomalainen kirjoittamisen opetus ennen ja nyt. Vesa Korhonen, Johanna Annala ja Pirjo Kulju (toim.): Kehittämisen palat, yhteisöjen salat: näkökulmia koulutukseen ja kasvatukseen, 157-180. Tampere University Press, Tampere. http://urn.fi/URN:ISBN:978-952-03-0500-o

Peterson, Shelley Stagg - Parr, Judy - Lindgren, Eva - Kaufman, Douglas 2018: Conceptualizations of writing in early years curricula and standards documents: international perspectives. The Curriculum Journal, 1-23. Taylor \& Francis, London. https://doi.org/10.1080/09585176.20 18.1500489

RANDAHL, ANN-CHRISTIN 2011: Elever som skribenter i skolans skrivpedagogiska diskurser. Lisensiaatintyö. Institutionen för svenska språket vid Göteborgs universitet.

Ranta, TuUla 2007: Kirjoittamisprosessi teksteinä. Tekstilingvistinen näkökulma abiturienttien tekstintuottamismenettelyihin. Joensuun yliopisto, Joensuu. http://urn.fi/URN:ISBN:978-952-219-084-0

Remillard, Janine T. - Heck, Daniel J. 2014: Conceptualizing the curriculum enactment process in 
mathematics education. ZDM Mathematics Education 46, 705-718. Springer, Cham. https://doi. org/10.1007/s11858-014-0600-4

Suoninen, Eero 1992: Perheen kuvakulmat. Diskurssianalyysi perheenäidin puheesta. Tampereen yliopisto, Tampere.

SvinhUfVUd, Kimmo 2016 [2007]: Kokonaisvaltainen kirjoittaminen. Kolmas, uudistettu ja täydennetty laitos. Art House, Helsinki.

SvinhufvUd, Kimmo - ERRA, SATU 2018. Kirjoittaminen lukio-opetusta ohjaavien dokumenttien valossa. Esitelmä Kirjoittamisen tutkimuksen päivillä 8.6.2018.

Valtonen, PäIvi 2012: Abiturientti uutistoimittajana. Tekstilajin taju ja uutisen tuottaminen äidinkielen tekstitaidon kokeessa. Turun yliopisto, Turku. http://urn.fi/URN:ISBN:978-951-29-5180-2

VisK = Hakulinen, Auli - Vilkuna, Maria - Korhonen, Riitta - Koivisto, Vesa - Heinonen, TARJA Rittta - Alho, Irja 2004: Iso suomen kielioppi. Suomalaisen Kirjallisuuden Seura, Helsinki. Verkkoversio. Saatavissa: http://scripta.kotus.fi/visk URN:ISBN:978-952-5446-35-7 [Viitattu 22.3.2018].

YTL 2012. Äidinkielen kokeen määräykset. 25.5.2012. Ylioppilastutkintolautakunta, Helsinki.

\section{SATU ERRA: Discourses of writing in reflective texts written by upper secondary school students}

This article discusses the discourses of writing present in reflective texts written by upper secondary school students. The analysis is based on Ivaničs (2004) framework, which can be used for identifying six discourses of writing: skills discourse, creativity discourse, process discourse, genre discourse, social practices discourse and socio-political discourse. I analyse 50 student essays and compare the findings with a previous study found in the National Core Curriculum for Upper Secondary School 2003 and the Regulations of the Finnish Matriculation Examination of the Mother Tongue (Erra \& Svinhufvud 2017).

The analysis shows that upper secondary school students' conceptions of writing differ from the way the curriculum and the matriculation examination are conceptualised, especially when it comes to creativity discourse. Students' essays are dominated by the skills discourse and creativity discourse, which are partly opposing views. Both discourses are also present in the curriculum and the matriculation examination, but not as strong. Process discourse is present in the curriculum but is practically absent from the matriculation examination. The texts written by students have some references to the process discourse, but few students report that they actually plan or edit their texts. The genre discourse is emphasised in both the curriculum and the final examination, and some students see writing as production of a genre. The lack of social and socio-political writing discourse in the students' views is in line with the curriculum and the matriculation examination.

This article argues that a comprehensive view of writing and paying attention to diverse writing discourses can be a useful starting point for developing upper secondary school writing instruction and assessment.

Satu Erra

satu.erra@gmail.com

Jyväskylän yliopisto, musiikin, taiteen ja kulttuurin tutkimuksen laitos 40014 Jyväskylän yliopisto 